\title{
A construção do fato científico: representações sobre células-tronco
}

\author{
Naara Luna ${ }^{1}$ \\ Universidade Federal Rural do Rio de Janeiro
}

RESUMO: O artigo aborda representações presentes no discurso de cientistas envolvidos em projetos de pesquisa básica com células-tronco (CT). O contexto é o campo científico, que abrange terapia celular, bioengenharia e medicina regenerativa. Trata-se de pesquisa etnográfica com observação e entrevistas semiestruturadas realizada em uma universidade. No exame do discurso dos cientistas entrevistados para a investigação, o objetivo é elucidar a construção das células-tronco como fato científico, o que remete ao debate antropológico sobre natureza e cultura. A análise dos discursos referentes ao histórico do conhecimento sobre células-tronco e às hipóteses explicativas de sua ação revela a dinâmica de construção de verdades científicas. Ao verificar as representaçôes existentes nos discursos sobre células-tronco, quer-se explorar a ciência como cultura. O laboratório é instância crucial para a construção dos fatos. A hierarquização de critérios como morfologia e fisiologia, para a constituição da identidade da célula, são elementos que estruturam o discurso dos cientistas.

PALAVRAS-CHAVE: Células-tronco, construção do fato científico, antropologia da ciência.

Este artigo aborda representações presentes no discurso de cientistas envolvidos em projetos de pesquisa básica com células-tronco ${ }^{2}$. As representações e os fatos dizem respeito ao campo científico em forma- 
ção, que abrange terapia celular, bioengenharia e medicina regenerativa. Segue-se aqui a linha de trabalhos antropológicos que investigam de que maneira categorias e/ou estereótipos culturais informam e modelam nossas concepções de mundo, no exame das representações letradas ou científicas (Salem, 1997: 78). Pretende-se examinar a construção social dos fatos naturais. Ao analisar o discurso de cientistas envolvidos em pesquisas com células-tronco e bioengenharia, o objetivo é elucidar a construção das células-tronco como fato científico.

Franklin (2001) sugere um afastamento das abordagens da bioética, na direção das categorias sociais cambiantes. Enquanto a bioética indaga acerca do certo ou errado e como se conhece o que se conhece, as disciplinas sociais interpretativas, como a antropologia, perguntam por que coisas significam o que significam, como o conhecimento é construído e como entendimentos são produzidos.

$\mathrm{Na}$ análise da constituição do conhecimento científico, uma noção instrumental é a "construção do fato científico" (Latour; Woolgar, 1997; Latour, 2000). Quando os entrevistados debatem em torno das hipóteses explicativas da ação terapêutica das células-tronco, os mecanismos que os fazem crer ou descartar uma hipótese, essa dinâmica de construção de verdades científicas se revela. Ao examinar as representações presentes nos discursos sobre células-tronco e medicina regenerativa, objetiva-se explorar a ciência como cultura (Franklin, 1995) e analisá-la como nosso mito, nos termos de Haraway (1991).

Este trabalho se baseia em observação etnográfica e em entrevistas com pesquisadores envolvidos em projetos com células-tronco de uma universidade pública. Em 2006, foram entrevistados 36 pesquisadores em laboratórios dos departamentos de Histologia e Embriologia, de Anatomia, e no Instituto de Biofísica, setores onde se encontrou densa rede científica (Latour, 2000) de pesquisadores em células-tronco. Aplicou-se entrevista semiestruturada com roteiro de questôes abertas e re- 
gistro gravado. O roteiro tinha três partes: a primeira sobre dados pessoais e a carreira dos pesquisadores; a segunda abordando o projeto de pesquisa com células-tronco, as perspectivas das pesquisas em geral, e a posição sobre questões conceituais; a última parte indagava a opinião sobre questões éticas e sociais referentes à pesquisa com células-tronco. Dezessete entrevistados eram professores e 19, alunos. O grupo de alunos compreende as categorias de pós-doutores, recém-doutores, doutorandos, mestres e mestrandos. No presente artigo, são mencionadas 17 dessas entrevistas.

\section{A ciência como objeto da antropologia}

No estudo da ciência como um sistema cultural, a contribuição da antropologia ilumina a presente investigação sobre as representações e a construção das células-tronco como fato. Emily Martin (1997: 132) explicita dificuldades para o estudo da ciência ocidental: seria possível pensar a ciência fora de si mesma? A principal dificuldade reside na visão de natureza sustentada pela ciência, que não se considera uma cosmovisão, mas pretende revelar a realidade. As ciências tomam como dado a "verdade" no sentido de: objetividade como ponto de vista, a natureza como objeto e a materialidade como realidade. Os cientistas têm a pretensão de descobrir a realidade, não de construí-la ou de serem construídos (Martin, 1997: 134).

Segundo Franklin (1995), a antropologia tem as ferramentas para compreender a ciência como forma de cultura, questionando-a como um sistema de crenças relativo aos fundamentos (foundational belief system). A avaliação da ciência como sistema de representação considera a fusão de dois aspectos, a técnica instrumental e o "real", pois a ciência é tanto o conhecimento do mundo natural expresso em termos natura- 
listas como os procedimentos para obter esse conhecimento. Culturas científicas locais estão embutidas em associaçôes transnacionais e em significados culturais mais amplos. Há o cruzamento entre a cultura do laboratório e a cultura mais ampla na qual se integra (Franklin, 1995: 173 ss.). Escobar (1994: 211) considera ciência e tecnologia arenas cruciais para a criação de cultura no mundo de hoje. Tecnologia representa invenção cultural, que emerge de condiçôes culturais particulares e ajuda a criar novas condiçôes.

A contribuição da antropologia para a análise da produção científica visa a um projeto etnográfico tradicional: efetuar um diagnóstico cultural inicial das práticas emergentes e as transformaçôes associadas com desenvolvimentos tecnocientíficos em ascensão (Escobar, 1994: 216), no caso, a pesquisa com células-tronco.

Latour e Woolgar (1997: 18) questionam os etnólogos que estudam as suas próprias sociedades ocidentais modernas por se restringirem ao enfoque do que é mais semelhante às sociedades "primitivas" ou "tradicionais". Como ciência da periferia, a antropologia tem dificuldade de se voltar para o centro, no caso, o estudo das ciências duras. Deve-se alertar para a dificuldade de se trabalhar na interface de duas ciências, como se pretende aqui. De modo semelhante ao estereótipo do antropólogo clássico, em estudo de populações "exóticas", que aprende a linguagem de seus nativos, no caso da antropologia da ciência é necessário apreender e analisar conceitos básicos, até para se demonstrar a construção do fato científico proposta pelo artigo. Por isso faz-se esse esforço de compreender alguns conceitos da biologia. 
Revista de Antropologia, São Paulo, USP, 2013, v. 56 No 1.

\section{O campo das terapias celulares e sua pesquisa: uma introdução a conceitos biológicos}

Célula-tronco é aquela "com capacidade de auto-renovação ilimitada/ prolongada, capaz de produzir pelo menos um tipo de célula altamente diferenciada", ou seja, a que "tem a capacidade de se dividir em células idênticas a ela ou em diferentes tipos de células" (Pereira, 2002: 65). Em termos esquemáticos: enquanto as células se dividem em outras idênticas à original, as células-tronco conseguem se dividir em uma célula indiferenciada (a célula-mãe) e em uma célula diferenciada, ou em mais de um tipo diferenciado. As células-tronco são distintas, no tocante à origem e ao potencial de diferenciação. Podem ser obtidas de embrióes nos primeiros dias de desenvolvimento (células-tronco embrionárias) e de outros tecidos (células-tronco adultas). O óvulo fertilizado até a fase de mórula (terceiro dia de desenvolvimento nos embriōes humanos) é uma massa compacta de células totipotentes, isto é, cada uma pode gerar um novo embrião. Retiradas do nó embrionário de blastocistos (em humanos são embriōes no quinto dia de desenvolvimento), as células-tronco são pluripotentes: não geram novo embrião, mas formam qualquer tipo de tecido (exceto os anexos embrionários: placenta, bolsa amniótica e cordão umbilical) (Rehen; Paulsen, 2007; Carvalho, 2001). Quanto à origem, existem também células-tronco de tecidos adultos. As células-tronco adultas podem ser isoladas de tecidos da própria pessoa, eliminando os problemas de rejeição em caso de transplante e de destruição de embriōes (Pereira, 2002). A possibilidade de transplante do próprio paciente foi fator decisivo para os primeiros ensaios clínicos terem recorrido a células da medula óssea (Rehen; Paulsen, 2007).

Pesquisadores tentaram comprovar que células-tronco adultas hematopoiéticas (da medula óssea) e neurais (do sistema nervoso) não seriam apenas multipotentes (geram tipos celulares de seu tecido de origem), 
como outros tipos de células-tronco adultas, mas também pluripotentes (geram células de outros órgãos e tecidos). Para os que defendem essa hipótese da plasticidade, a origem embriológica não limita o potencial das células-tronco neurais e da medula óssea: estas poderiam se diferenciar em qualquer tipo de célula, desde que cultivadas em condições adequadas. A pluripotencialidade das células adultas abriria a possibilidade de transplantes de tecidos do próprio paciente (autólogos) sem rejeição (Carvalho, 2001). Isso significa que seria possível extrair células da pessoa, cultivá-las em laboratório para formar tecidos e transplantá-los de volta para ele. Pereira (2002) considera que dois fatores limitam o uso de tais células em transplante: a raridade de células-tronco adultas com uma capacidade de diferenciação tão ampla como as embrionárias, e a perda rápida da capacidade de divisão e diferenciação das células adultas, em contraste com as derivadas de embrióes. O alcance da plasticidade tem sido contestado e é objeto de debate da comunidade científica, conforme verificado no discurso dos informantes. Em 2007, ano posterior ao trabalho de campo retratado, publicou-se pesquisa em que se reprogramaram células comuns a adquirir a pluripotencialidade das células-tronco embrionárias, a partir de manipulação genética (Rehen; Paulsen, 2007) ${ }^{3}$.

Nova especialidade estabelecida no campo médico, a medicina regenerativa visa ao reparo ou à substituiçãa de tecidos que sofreram lesão ou degeneração (Borojevic, 2004). A engenharia tecidual pretende criar tecidos em laboratório com a finalidade de reparo de órgãos lesados e das consequências do envelhecimento. A medicina regenerativa é seu campo de aplicação, combinando células, materiais e fatores. Daí a relevância da capacidade regenerativa das células-tronco (Rehen; Paulsen, 2007). O uso de células-tronco permitiria recriar tecidos e repetir sua geração. A medula óssea é a principal fonte de obtenção de células-tronco para terapias. A capacidade das células-tronco de regene- 
rar in situ estruturas teciduais complexas e funcionais é crítica para seu uso em medicina regenerativa. Algumas terapias regenerativas se dirigem à construção, em laboratório, de tecidos para implante. Já se demonstrou in vivo a funcionalidade das células-tronco. A bioengenharia, ou terapia celular reparadora, pode ser usada em lesões traumáticas com perda de tecidos ou órgãos. Em doenças degenerativas, seria terapia paliativa. Há objeções éticas ao uso de células embrionárias e obtidas de clonagem, mas não ao uso das células do próprio paciente (Borojevic, 2004).

Retomando as questões iniciais a partir do campo de investigação, indaga-se: que representações estão envolvidas na construção do conceito de células-tronco? Como começou esse conhecimento?

\section{$\mathrm{O}$ início das pesquisas}

Perguntou-se aos entrevistados o que conheciam sobre a história das pesquisas com células-tronco. A maioria hesitou para responder. Uma professora adjunta (46 anos) comentou que não dava importância ao que ficou registrado em livros. As respostas vieram dos que eram mais antigos no campo de investigação com células-tronco, no caso dos professores, ou de alunos que se direcionaram a esta área específica de pesquisa. Tendo conhecido o objeto células-tronco já pronto e fechado nas abordagens de divulgação científica, foi uma surpresa, na presente investigação, constatar que as pesquisas com células-tronco adultas e com células embrionárias ocorreram de modo independente, conforme se depreende da resposta desse professor titular (65 anos):

As primeiras terapias celulares são um transplante de medula óssea. Nós [comunidade científica] fazemos transplante de medula óssea há quarenta 
anos. Nós começamos aqui no hospital [...] em 94. É o início das terapias celulares e é o início do conceito de células-tronco.

Solicitado a expor um histórico das pesquisas com células-tronco, o professor titular afirma:

O histórico começou, então, com identificação de células-tronco e definição de células-tronco. [...] Dentro dos humanos, as primeiras células-tronco caracterizadas são as células-tronco de tecido sanguíneo. Nós trabalhamos durante muito tempo com esses conceitos de tecido sanguíneo. Nós sabemos também, há um tempo, que dentro dos tecidos existem células que têm a capacidade de participar da regeneração, por exemplo, na pele existem células que vão participar da regeneração da pele se você sofrer uma queimadura, mas que também regeneram bulbo capilar, glândula sebácea e glândula sudorípara. [...] A manipulação clínica dessas células começou francamente nos anos 2000 e, a partir desse momento, nós começamos a utilizar em clínica essas células, principalmente as células retiradas da medula para o reparo de tecidos periféricos.

Esse professor titular associa o início das terapias celulares com os transplantes de medula óssea a um marco para o estudo e o conhecimento das células-tronco. Ele destaca o conhecimento prévio sobre regeneração. Uma professora adjunta (40 anos) também recorda o estudo das células-tronco na hematopoiese (produção do sangue):

Célula-tronco é muito conhecida desde a década de 60 , porque já se estudava há muitas décadas. Se estudava célula-tronco, a única conhecida até então no sangue, a que regenera todas as células sanguíneas e fica na medula óssea vermelha. Ela foi muito explorada na década de 60 e a partir daí 
Revista de Antropologia, São Paulo, USP, 2013, v. 56 no 1.

vieram os transplantes de medula óssea. A partir da década de 90, foram caracterizados e descritos outros tipos celulares diferentes da célula hematopoiética, que é do sangue. Então, aos poucos, a cada ano foi saindo, depois a cada mês, uma nova célula-tronco em algum órgão: pâncreas, fígado, músculo e no próprio cérebro [...]. Isso em relação às células-tronco do adulto, células-tronco maduras.

Ela destaca o caráter dinâmico da produção de conhecimento, com a emergência de células-tronco em outros órgãos além do tecido sanguíneo. Em seguida, a mesma professora adjunta rememora o início dos estudos com células-tronco embrionárias.

Nos Estados Unidos, também se identificou, primeiro em camundongo, no início da década de 80 , uma célula-tronco embrionária a partir de linhagens embrionárias de camundongo. E depois apareceram as primeiras células-tronco embrionárias humanas também nos Estados Unidos na década de 90. [...] Muitos laboratórios em todo o mundo acessam essas linhagens que são cerca de 150 linhagens de células estabelecidas a partir de embriōes humanos. E outros laboratórios tentam estabelecer novas linhagens embrionárias. E muitos trabalham com células-tronco maduras.

Houve inicialmente a identificação de células-tronco em embriões de camundongo, e o cultivo e isolamento dessas linhagens, no início da década de 1980. No final dos anos 1990, foram isoladas as primeiras células-tronco embrionárias humanas. A professora destaca sua opção por trabalhar apenas com as células-tronco adultas.

Dentre os entrevistados, apenas uma doutoranda (30 anos) reportou-se imediatamente ao início das pesquisas com células-tronco embrionárias: "Em 81, Kaufman e Evans conseguiram derivar a primeira 
célula-tronco embrionária de camundongo [...]. Pegando um embrião de camundongo na fase de blastocisto". O estudo iniciado na década de 1950 em teratomas (tumores de origem embrionária que contêm vários tecidos desorganizados) de camundongo serviu de base para que:

Quando eles extraíram as células-tronco embrionárias de camundongo, que eles conseguissem manter essas células em cultura durante um bom tempo. Até se conseguir extrair as primeiras células embrionárias humanas, passaram-se quase dezoito anos. Foi em 98. Vieram de embriōes de clínicas de fertilidade, que estavam congelados há muito tempo, que não iam mais servir para implante. Conseguiram extrair essas células e cultivar basicamente do mesmo jeito que fizeram com células de camundongo. E a partir daí [...], foram derivando cada vez mais células, descobrindo novas metodologias mais eficientes para cultivo e manutenção sem que ela se diferenciasse ou tivesse uma mudança de cariótipo muito expressiva.

Foi a partir do estudo desses tumores em camundongo que se adquiriu técnica para o cultivo de células-tronco embrionárias. As células-tronco embrionárias humanas foram obtidas de embriōes descartados na fertilização in vitro.

Conclui-se que, embora as células-tronco estejam agregadas nos discursos da divulgação científica como duas variedades da mesma coisa, diferindo quanto à origem e potencial (Pereira, 2002), as pesquisas com células-tronco adultas e embrionárias se desenvolveram por vias distintas. Hoje também se associa terapia com células-tronco e engenharia de tecidos ou bioengenharia tecidual, embora a origem dessas linhas seja diferente. 


\section{Novas formas de vida "engenheiradas"}

Franklin (2005) sugere a abordagem de células-tronco como forma de vida emergente e distintiva, que reconfigura compreensōes tradicionais de economia, governo e biologia. Nas descrições de células-tronco percebem-se modelos emergentes de vida humana, em que o que somos e aquilo de que somos feitos pode ser extraído e utilizado de modos que não são apenas a reutilização de partes existentes, mas sua redefinição. A redefinição do humano como uma quantidade de células com qualidades diferentes é mais elaborada em termos da habilidade de quebrar capacidades celulares em funçōes específicas e redesigná-las. Nesse estágio inicial da pesquisa com células-tronco, uma linguagem dominante de capacidade celular associa-se à extração de funções e efeitos específicos. A linguagem da engenharia e do design, aplicada a unidades fundamentais do corpo, as células, oferece perspectivas de formas de vida que podem ser utilizadas para incrementar vários tipos de vida. Esta linguagem está explícita no comentário de um professor adjunto (53 anos) sobre perspectivas futuras das pesquisas com células-tronco:

Elas podem levar à construção em laboratório de peças anatômicas. Engenharia de tecidos, ou fazer tecidos em laboratório. [...] [A célula-tronco] funciona como um repositório biológico de peças. [...] A partir do momento em que se estabelecer [...] o conhecimento básico de célula-tronco, se tiver esclarecido as etapas de diferenciação, vários laboratórios vão começar, com esse conhecimento, a tentar reconstruir, a fazer peças anatômicas inteiras. [...] O futuro dessa história toda vai ser fazer engenharia de tecidos, então fazer tecidos homólogos, ou seja, do próprio paciente, no laboratório, e construção de órgãos e biomateriais cada vez mais bio e menos material. Cada vez mais, esses biomateriais (implantes 
metálicos, implantes de polímeros) vão passar a ter uma relevância, um componente biológico cada vez maior em detrimento do componente metálico, ou químico, ou polimérico.

Essa declaração explicita a representação das células-tronco como instrumentos mecânicos: o "repositório biológico de peças" remete ao uso da plasticidade das células na engenharia de tecidos para a construção de órgãos. Segundo Hogle (2003), as representações de vida brotando de engenharia baseada em biologia criam novas possibilidades para intervir em vida, saúde e trabalho. No "biomimetismo", uma célula pode ser convertida para uso em uma parte corporal na qual ela não seria normalmente encontrada, o que levanta novas possibilidades de design: substitutos de tecidos não precisam funcionar exatamente como o original, órgãos não vão para seus locais de origem (Hogle, 2003). No trabalho de campo, na maioria dos experimentos pré-clínicos com terapia celular em modelo animal, observou-se o uso de células extraídas da medula óssea para aplicação em problemas não hematológicos, quebrando o paradigma anterior de fazer o transplante de medula para curar doenças hematológicas (Luna, 2006), conforme descrito na história das pesquisas. A plasticidade das células-tronco, interpretada antropologicamente como biomimetismo por Hogle, situa-se na base das representaçóes presentes nas expectativas sobre células-tronco. Uma médica recém-doutora (37 anos) afirma: "O legal da célula-tronco é que ela vai virar o que precisa”. Uma doutoranda (28 anos) relata expressóes ouvidas dos que não são pesquisadores: "Por terem essa capacidade de se diferenciar, muita gente fala: as células do milagre!”. A representação das células-tronco passa para o plano sobrenatural. Outra pesquisadora com mestrado (45 anos) reflete sobre a recepção do assunto: 
Revista de Antropologia, São Paulo, USP, 2013, v. 56 no 1.

Quando você fala hoje em célula-tronco, que é uma coisa que tem complexidade, qualquer pessoa leiga já ouviu falar. [...] Célula-tronco já caiu no gosto popular, na mídia. [...] As pessoas não têm a noção do que de fato é esse mecanismo, parece uma coisa mais mágica... [...] Parece uma coisa mágica que você vai colocar lá e "pum!", funcionou.

Além de pesquisadora, ela é profissional de saúde e recebe as perguntas de seus pacientes: “[...] no 'Fantástico' tem uma mágica que acontece e as pessoas chegam no dia seguinte e querem: 'aonde tem aquilo? Eu quero para minha filha!" . As promessas de potencial terapêutico extraordinário, veiculadas na mídia, inserem as representaçóes das terapias no plano mágico-religioso, como agentes de cura milagrosa.

Com o propósito de comparação, vai-se relacionar a classificação das células, seu uso inovador nas práticas experimentais das terapias celulares e da bioengenharia de tecidos, e as expectativas divulgadas pela mídia. A biomedicina classifica as células de acordo com seu potencial de diferenciação: as totipotentes podem gerar um ser completo; as pluripotentes são capazes de se transformar em qualquer tipo de tecido (exceto os anexos embrionários); as multipotentes se transformam em tipos oriundos do mesmo folheto embrionário. As terapias celulares e a engenharia de tecidos se apropriam dessa plasticidade a fim de redesignar as células-tronco para novas funções (Hogle, 2003). Nesse sentido, um dos cientistas entrevistados as comparou a um "repositório biológico de peças". As aplicações estendem o potencial das células e propiciam expectativas clínicas inéditas, o que, divulgado pela mídia, gera a representação popular de caráter mágico-religioso de células do milagre. 


\section{Gênese do fato científico: proto-ideias, fatos e artefatos}

Nas entrevistas, constatou-se certa fluidez do conceito de células-tronco e das áreas de terapias com células-tronco e bioengenharia tecidual, termos utilizados pelos entrevistados. Para compreender a fluidez em conceitos científicos, é possível recorrer às análises de Fleck em La génesis y el desarollo de un hecho científico (1986) e de Latour e Woolgar (1997). Segundo Schäfer e Schnelle (1986), Fleck considera que o pensar médico está em tensão permanente entre o desejo de unificação teórica, que só se pode obter por meio da abstração, e a necessidade de concretizar as afirmações, o que obriga a uma multiplicidade de colocações opostas. O saber médico é uma corrente na qual certas ideias e pensamentos diretores acabam formando pontos de vista dominantes. Porém, estas são sempre meras concepções específicas e temporais, que se transformam dinamicamente em novas orientações. Nos processos de aparição e desaparição dessas orientações dominantes, haveria tanto sucessão como coexistência de critérios conceituais incomensuráveis (Schäfer; Schnelle, 1986: 20). Quando os entrevistados se referem a terapias celulares, bioengenharia ou pesquisa com células-tronco, há áreas comuns que se superpõem, mas não coincidem totalmente. Fleck (1986) demonstra esse caráter histórico do saber por intermédio do conceito de proto-ideias. Nas entrevistas, percebeu-se a existência dessas proto-ideias quando o professor titular (65 anos) comentou que o início das noções ligadas às células-tronco remontava ao século XIX:

Nós as conhecemos há um século, porque nós sabemos que o tecido se regenera, e os estudos em animais mais primitivos são os estudos que eram muito úteis, porque os animais mais primitivos têm uma capacidade de regeneração maior. Os anfíbios podem regenerar um membro inteiro. Então esses modelos foram primeiro estudados. 
Revista de Antropologia, São Paulo, USP, 2013, v. 56 no 1.

O estudo da regeneração em animais inferiores já existia antes do conceito de células-tronco. Outro exemplo de proto-ideia é a noção de células indiferenciadas, anterior à de células-tronco. $\mathrm{O}$ professor adjunto de 53 anos comenta acerca da mudança da identificação antiga para o conceito novo:

Esse conceito de stem cell é um pouco recente, agora a identificação das stem cells é coisa antiga. [...] Nos anos 60, anos 70, em livros clássicos de histologia. [...] Tinha livros de histologia que falavam de células indiferenciadas. Determinadas regiōes do nosso corpo ou de órgãos, em que existiam células indiferenciadas. [...] Avançando a tecnologia para se utilizar em laboratório tanto das microscopias eletrônicas, de ensaios bioquímicos, ensaios moleculares, se começou a ver aquela montanha de células indiferenciadas de uma outra maneira. Porque já existiam técnicas para se investigar o que tinha naquelas células. E começaram [...] os primeiros trabalhos. [...] Então são células que podem se diferenciar em qualquer coisa: a tal da plasticidade. [...] Esse nome stem cell que foi mal traduzido para a gente como célula-tronco. Tronco, para o americano stem, faz sentido: um negócio do qual vão saindo galhinhos. Então para a gente, galhinhos quer dizer plasticidade, diferenciação em vários modelos celulares.

O professor identifica as células-tronco como as células indiferenciadas dos livros de décadas anteriores. Sua perspectiva, como observou Martin (1997) sobre as ciências naturais, é de ter ocorrido apenas a descoberta da realidade, de algo já dado. Mesmo que células indiferenciadas tenham sido registradas antes, pode-se objetar que o conceito de célula-tronco é recente e tem significados que vão além da propriedade de indiferenciação, conforme se verá adiante. A mudança de concepção de "fenômenos" ao longo da história do conhecimento evidencia o caráter socialmente construído dos fatos. Latour e Woolgar (1997) observam 
que dificilmente cientistas aceitarão o ponto de vista de que fatos são socialmente construídos, pois compreendem que seu ofício é revelar a existência dos fatos. Os próprios fatos se recusam a ser sociologizados e querem voltar ao seu estado de exterioridade. Latour e Woolgar (1997: 33 , n. 11) se referem à transformação do enunciado em fato. Os autores entendem por fato "um 'enunciado' que não está mais acompanhado por qualquer outro enunciado que modifique sua natureza". Essa definição pode se aplicar a qualquer fato, inclusive a uma teoria. Quando os fenômenos são constituídos pelos instrumentos usados em laboratório, constrói-se uma realidade artificial que passa por objetiva: essa realidade ou fenomenotécnica toma a aparência do fenômeno no próprio processo de sua construção pelas técnicas materiais (Latour; Woolgar, 1997: 61). Fatos e artefatos correspondem a enunciados situados em um continuum, que pode fazer referência ou não às condiçóes de sua construção, isto é, as condições de construção do artefato são lembradas e as do fato são ocultadas. No processo de construção dos fatos, certos dispositivos dificultam detectar traços de sua produção. A exterioridade do fato não é a causa do trabalho científico, mas sua consequência: a realidade é decorrente da estabilização do enunciado (o que não significa para os autores que os fatos ou a realidade não existam). A suspensão da controvérsia sobre certo fato ou a aceitação da validade do fato científico fora do laboratório é um dos pontos na direção de se aceitar sua correspondência com a realidade. Na etnografia da atividade de laboratório, constata-se que o caráter "objetivo" de um fato é consequência do trabalho do laboratório. Os fatos são construídos de modo que, uma vez resolvida a controvérsia, sejam tomados por fatos adquiridos. Latour (2000) usa a expressão "caixa-preta" para se referir aos fatos adquiridos ou estabilizados, cujas condições de produção ficam ocultas (daí a caixa-preta) e, enquanto isso não ocorrer, haverá o processo de disputa chamado con- 
trovérsia. Descreve-se aqui esse conceito de forma simplificada: em uma controvérsia, a cada nova contestação, o estatuto de uma descoberta será modificado. Os argumentos serão calcados em trabalho de laboratório e na literatura técnica que vai arregimentar aliados para a tese defendida mediante a citação de outros artigos científicos. Se não for estabilizado, se não alcançar o estatuto de fato, o objeto sob disputa será tomado como artefato, uma mera ficção resultante dos processos técnicos e teóricos, que são visíveis, e terá seu estatuto de fenômeno científico questionado. Nesses termos, será a célula-tronco um fato já adquirido? O enunciado sobre células-tronco já se estabilizou?

\section{A célula-tronco existe? Definição da célula}

Um cientista do Reino Unido entrevistado por Franklin (2005: 73 ss.) discorre sobre a dificuldade em padronizar o estudo com células-tronco embrionárias humanas, uma vez que pesquisadores utilizam diferentes métodos de cultura. Levou-se dez anos para aprender o melhor método de cultivar as linhagens de células embrionárias de murinos (ratos), e mais dez para se decidir como caracterizá-las. Há dificuldades em padronizar métodos de cultura e estabelecer critérios estáveis para padronizar as linhagens celulares humanas.

Um dos empreendimentos científicos desse campo é caracterizar os diferentes tipos de célula-tronco. Definições precisas são contrapostas à dificuldade de caracterização empírica, o que demonstra o caráter fugidio dessas células. Na definição de célula-tronco pela professora adjunta (46 anos), ressalta-se o aspecto indiferenciado, sua falta de identidade. Ela especula se o estado indiferenciado consiste no fator que as qualifica para empreender reparos. 
Seriam células indiferenciadas; não têm uma identidade própria; estariam no organismo para fazer os reparos que ocorrem naturalmente na fisiologia com o envelhecimento, e poderiam ser utilizadas em insultos [danos] fisiopatológicos mais graves, onde o organismo não consegue se recuperar sozinho.

Se as células-tronco já estão no organismo para reparar o que se degenerou com o envelhecimento, elas podem ser extraídas para uso em tratamento de danos mais graves. Um recém-doutor de 27 anos dá uma definição técnica de célula-tronco:

A célula-tronco é definida por duas características: ela tem que ter certa potencialidade; ela tem que gerar um número de células diferenciadas. Esse número varia dependendo da categoria de célula-tronco. Mas ela tem que ter como categoria uma habilidade específica que realmente define a célula-tronco: capacidade de autorrenovação. Num processo normal de divisão celular, uma célula X, quando divide, vai gerar duas células X. [...] No processo de divisão assimétrica da célula-tronco, uma célula é exatamente igual à célula-mãe e a outra célula é a que vai entrar na cascata de diferenciação e formação das células especializadas. Ela tem capacidade de fazer com que uma célula sempre se mantenha no sistema, sempre se autorrenove: isso é o que realmente define uma célula-tronco.

A célula-tronco caracteriza-se por sua divisão assimétrica em outra célula-tronco idêntica, e uma célula-filha mais diferenciada. Franklin (2005) chama as células-tronco de "multiplicadores multitalentosos", devido à excepcionalidade de sua reprodução idêntica e capacidade de diferenciação: é isso que permite a reprodução infinita de uma célula igual à célula-mãe, ao mesmo tempo em que garante a diferenciação das células por ela geradas. Um ponto de destaque na produção de enuncia- 
Revista de Antropologia, São Paulo, USP, 2013, v. 56 no 1.

dos sobre células-tronco é o uso da linguagem de parentesco: célula-mãe, linhagens de células e até células progenitoras, como se constata no depoimento do recém-doutor de 27 anos.

Quando uma célula-tronco dá origem às células diferenciadas daquele tecido no qual se encontra, ela gera células cada vez mais comprometidas com uma linhagem ou com outra [...] à medida que ela caminha na cascata de diferenciação [...]. Quando a célula perde a capacidade de autorrenovar e ela vai sendo específica cada vez mais para um tipo celular, ela não é mais uma célula-tronco, ela é uma célula progenitora. A célula progenitora é diferente da célula-tronco. A célula-tronco tem baixa taxa de proliferação: ela se divide muito lentamente. Ao contrário, os progenitores têm altas taxas proliferativas e são as células responsáveis pela expansão do grande número de células especializadas formadas ao final [...] Tem que tomar cuidado com o termo progenitor, porque é um termo que muita gente usa para definir as próprias células-tronco.

Com a diferenciação contínua em vários níveis, ou cascata de diferenciação, a célula perde seu caráter indiferenciado na autorrenovação. Passa a ser denominada de célula progenitora, dela se originando um grande número de células especializadas. O próprio depoente alerta para a confusão, pois se utiliza o termo "progenitor" para definir célula-tronco. De fato, na presente investigação, uma mestranda de 22 anos entrevistada se refere à designação "progenitores neurais" e "células-tronco neurais" para descrever sua pesquisa.

O mesmo recém-doutor de 27 anos comenta sobre o vazio do termo quando indagado sobre a ação terapêutica dessas células. "Eu sempre costumo dizer que o termo 'célula-tronco' não diz nada. Você tem que saber exatamente qual é o adjetivo que segue o termo 'célula-tronco', para aí saber com que está trabalhando, quando a gente vai pensar em 
terapia." Para esse recém-doutor, a expressão "célula-tronco" necessita de qualificação, para se saber com o que se está trabalhando em uma terapia. Outra médica e professora adjunta (52 anos) questiona o correlato empírico para o conceito de célula-tronco:

Eu acho que não existe nenhuma definição que seja completa. O que a gente chama de célula-tronco e divulga eu não sei se existe ou se alguém já isolou. Seria uma célula só. Mas o que a gente usa normalmente como célula-tronco seria uma célula capaz de gerar qualquer tipo celular dentro do indivíduo, a depender da manipulação que ela vá sofrer. [...] Nem todo mundo trabalha com células-tronco. As pessoas geralmente trabalham com células totipotentes, ou multipotentes, e são células que já têm alguma definição. Já não podem mais gerar qualquer tipo celular. Mas elas podem gerar alguns tipos celulares e, a depender do ambiente que você propicia para essas células, elas podem então escolher um desses caminhos.

Enfatizando o aspecto de pluripotencialidade, a professora aponta a identificação empírica desse objeto, ao definir célula-tronco como aquela capaz de gerar qualquer tipo celular do organismo. Essa pesquisadora com mestrado ( 45 anos) considera que se tem abusado do uso do conceito "célula-tronco", como se qualquer célula utilizada para "otimizar a regeneração", isto é, em terapia, fosse célula-tronco.

Para você dizer que uma célula é célula-tronco, tem uma série de coisas a serem avaliadas. As pessoas dizem hoje que qualquer célula que você póe [para otimizar a regeneração] é uma célula-tronco. [...] Mais da metade do que se fala não é bem assim. [...] Principalmente quando sai na mídia, os critérios têm que ser mais rastreados. 
A professora adjunta (46 anos) prefere a expressão "terapia celular" à "terapia com células-tronco" por considerar que não se isolam apenas células-tronco para terapia, mas um "coquetel” de células da medula óssea.

Prefiro chamar de terapia celular, porque a gente está trabalhando com um coquetel de células. Dentro desse coquetel de células, você tem a célula-tronco. Eu ainda não estou convencida se eu preciso realmente selecionar só a célula-tronco e se ela sozinha, indo para aquele ambiente, vai seguir o programa que eu imagino que vai acontecer. Se ela precisa desse coquetel de células que deem informações, fatores que vão ajudá-la na hora que ela estiver nesse ambiente. Eu prefiro chamar de terapia celular, porque você não está isolando ainda e você não tem ainda uma resposta de que a célula-tronco sozinha é a forma. A gente não tem ainda uma formulação de célula, ou somente de célula-tronco, para dizer: "eu só estou aplicando célula-tronco". Você está fazendo uma terapia celular que envolve uma série de células em diferentes estágios de diferenciação, incluindo a célula-tronco.

A professora adjunta (46 anos) assegura que são utilizadas células em diferentes estágios de diferenciação, e não apenas a célula-tronco. Também uma professora adjunta de 52 anos reconhece que as propostas de terapia celular envolvem outras células, e não exclusivamente as células-tronco: "Acho que é melhor falar um pouquinho dessa questão da célula-tronco que às vezes não é exatamente tronco". Em seguida, essa entrevistada descreve três possibilidades de terapia celular autóloga (com células do próprio paciente), integrantes de seus projetos de reparo ósseo: 
1. Uso de células adultas diferenciadas que são cultivadas, ou seja, são utilizadas células comuns diferenciadas e não células-tronco para a terapia.

2. Terapia com fração mononuclear de células da medula óssea, separada do aspirado de medula e reinjetada na lesão ${ }^{4}$. Trata-se do mesmo procedimento que a outra professora designou de coquetel de células. Esse é o procedimento mais comum, que é praticamente sinônimo de terapia com células-tronco.

3. Terapia com células-tronco mesenquimais (ou estromais, são células de sustentação) de medula, extraídas da fração mononuclear e cultivadas em laboratório e depois reaplicadas no local.

\section{A identidade da célula}

Com respeito à construção do fenômeno célula-tronco, é fundamental, na pesquisa básica, a busca da identidade da célula, principalmente sua caracterização fenotípica ${ }^{5}$, os marcadores que a singularizam, objetivo de alguns projetos. Uma doutoranda (25 anos) descreve sua pesquisa de caracterização de células-tronco de adipócitos (tecido de gordura), diferenciando-as das células mesenquimais de sustentação:

Tem uma parte mais básica do meu projeto que é a busca da identidade dessa célula. É caracterização fenotípica, de marcadores. Quem é essa célula? Onde está essa célula? Eu faço ensaios de hematopoiese para ver se [...] a célula, antes de formar, tem um progenitor mesenquimal comum: aí a célula vai para o tecido adiposo ou vai para a medula.

Ao buscar a identidade da célula-tronco de adipócitos, ela verifica se existe uma mesma célula progenitora mesenquimal da qual se derivam 
os adipócitos e as células do estroma da medula óssea. Ela descreve como faz para separar em laboratório, dentre as células de medula óssea, a célula-tronco hematopoiética e a mesenquimal:

A célula hematopoiética, células sanguíneas são células redondinhas que não aderem no plástico. A gente usa aqueles plásticos de cultura, de garrafa. [...] Já a célula mesenquimal [...] faz parte do estroma do tecido. O papel dela na medula é sustentar essas células hematopoiéticas. É ter um arranjo tridimensional para aquelas células. [...] Ela tem essa característica de aderir ao plástico.

A separação se dá pela propriedade de aderência da célula à garrafa plástica do teste. Ela explica a caracterização fenotípica das células:

Cada célula [...] tem a sua identidade, seus marcadores de superfície. Se você olhasse a superfície de uma célula, ela tem expressões de várias proteínas. $\mathrm{O}$ que a gente faz é identificar essas proteínas através de marcadores. [...] E aí a gente incuba com anticorpos que são marcadores contra aquelas proteínas de superfície. Eles são genericamente chamados de CD.

Conforme a descrição, cada célula "tem" uma identidade referente a proteínas que estão na superfície (membrana). Contudo, as proteínas não são evidentes e para identificá-las é necessário fazer reação em laboratório com anticorpos chamados CDs, que marcam as proteínas. Eis novamente a construção do fato: como são obtidos os marcadores de superfície das células? É também a construção de outro fato: qual a origem dos anticorpos $\mathrm{CD}$ marcadores?

[CD] é Cluster Diferentiation em inglês. Tem mais de quatrocentos CDs. [...] Esses CDs já são comerciais. Você compra e sabe [o que o CD identi- 
fica]. O CD34 é o identificador de célula-tronco hematopoiética. [...] Para a célula-tronco mesenquimal, não tem um marcador específico ainda. Para a hematopoiética já é comprovado, é a 34. [...] Isolaram a [célula] 34 [...] e fizeram vários ensaios e viram que aquela realmente é a célula-tronco hematopoiética. [...] Para a mesenquimal, ainda não tem marcador específico. [...] A única coisa que a gente sabe com certeza da célula mesenquimal atualmente é que ela adere no plástico. [...] Ainda tem pouca pesquisa em relação a ela. Tem muita em relação à hematopoiética.

Esse exemplo explicita mais claramente o quanto a construção do fato científico, como afirmam Latour e Woolgar (1997), depende do trabalho de laboratório, em particular do instrumento técnico para a construção do fato. Anticorpos identificados como marcadores contra proteínas de superfície de células específicas, designados genericamente de CD (Cluster Diferentiation), são produzidos e comercializados por laboratórios. Segundo Cambrosio e Keating (apud Löwy 1994: 242), esses anticorpos monoclonais "são um exemplo de reagentes produzidos em laboratório que moldaram a prática de um campo científico dado e levaram ao desenvolvimento de novos 'fatos científicos'”. A difusão dos soros anti-CD padronizados contribui para a padronização dos laboratórios e para a redefinição do campo de estudo dos leucócitos. O CD34 é o identificador de célula-tronco hematopoiética, com uso difundido. Em levantamento bibliográfico de artigos científicos de revisão sobre células-tronco, constatei diversos que designavam tais células diretamente por CD 34: o teste promove a nomeação, o que confirma os achados de Cambrosio e Keating, e as observaçóes de Latour e Woolgar, com respeito à dependência do instrumento técnico para a criação dos fatos. Sem identificação dos marcadores da célula do estroma da medula óssea, a forma de separá-la das células hematopoiéticas é por 
aderência ao plástico, aderência que é atributo de célula de tecido de sustentação, em contraste com a célula hematopoiética geradora de células do sangue redondas, que circulam.

\section{Construção do fato nas células-tronco: os critérios e a controvérsia sobre sua ação}

Latour e Woolgar (1997) discorrem sobre práticas de interpretação no laboratório, que constroem o mesmo objeto ora como fato, ora como artefato. Tais práticas de interpretação estarão sob análise a partir dos depoimentos que discutem os parâmetros pelos quais se considera ou não que a célula se diferenciou em célula de tipo diferente: marcadores, morfologia e função. Como se constrói o fato? Um professor adjunto de 35 anos fornece células para que outro laboratório empreenda ensaio pré-clínico de terapia de lesão medular em modelo animal. Já injetaram células-tronco neurais nas cobaias. Ainda não injetaram as embrionárias, pois é necessário primeiro efetuar a pré-diferenciação: " $E$ as embrionárias, a gente vai fazer a pré-diferenciação com fatores que vão tornar a célula mais como um progenitor neural para depois injetar". Ele comenta que já conseguiram diferenciar células embrionárias de rato e humanas:

A diferenciação é um pouco genérica demais. [...] A gente usa um marcador para mostrar que aquela célula é um neurônio, mas ela é muito genérica. Você tem vários tipos de neurônio. [...] Agora a gente tem que esmiuçar os tipos neurais que você pode gerar. [...] Eu tenho uma foto aqui para mostrar. [...] O verde é quando você transforma essa célula em neurônio. [...] É um marcador neuronal. Está induzindo a diferenciação neural dessas células. 
O professor adjunto de 35 anos reconhece que a diferenciação de célula embrionária para progenitor neural ainda é genérica. Ele mostra na tela do computador a imagem do marcador neuronal da célula. Outros pesquisadores criticam esse tipo de interpretação. Consideram que a evidência apenas de marcadores é insuficiente para demonstrar a diferenciação da célula. Recordo aqui a observação de Latour e Woolgar (1997) sobre práticas de interpretação que constroem como fato ou como artefato. A partir da controvérsia sobre as hipóteses de ação terapêutica das células-tronco adultas, vai se prosseguir o exercício acerca de sua construção como fato científico. Um doutorando de 28 anos critica a teoria da transdiferenciação: a célula-tronco de um tipo de tecido se transformaria em célula adulta de tecido de origem embrionária diferente. Essa concepção, se provada, rompe com interpretações clássicas da biologia:

Lançaram uns três [artigos] destacados: "de sangue para neurônio" e "de neurônio para sangue". Acho que de fígado também. [...] Eu vi um artigo que era uma célula oval, uma célula hepática era injetada em cérebro de rato e se transdiferenciava numa glia [célula do sistema nervoso que não transmite impulso]. Pelo menos ela dizia que era uma glia pelos marcadores. Está lá naquele artigo, mas falta retratar, falta um monte de coisa, então dá para criticar bastante. A frequência é mínima. Diferencia? [...] Não se pode dizer que está exercendo a função de neurônio, só porque ela está com aquele fenótipo não quer dizer que ela está atuando. $O$ importante é que a célula que se diferenciar, que ela funcione. A função é a coisa mais importante que a célula tem que desenvolver, se ela se diferenciar num tipo celular e ser funcional, porque ela pode se diferenciar e não exercer papel nenhum.

O depoimento defende a tese de que a observação dos marcadores não bastaria para identificar o fenômeno da transdiferenciação, tratan- 
do-se de um artefato. $\mathrm{O}$ doutorando critica a conclusão baseada apenas na identificação de marcadores, um dos critérios morfológicos, ou do fenótipo da célula. Ele hierarquiza: a função prevalece sobre o fenótipo, pois não basta a célula se diferenciar e não exercer papel.

Um outro doutorando (28 anos) tem compreensão semelhante ao descrever a biologia das células-tronco e apresenta outras hipóteses quanto à sua ação terapêutica, que são alternativas à possibilidade de diferenciação: secreção de fatores e fusão.

Muito da discussão é de que a célula-tronco atue na melhora através de diferenciação: virando neurônio e substituindo uma população que morreu, ou virando glia. Outra hipótese é de secreção de moléculas por essas células, moléculas que estariam contribuindo para a reestruturação daquela população que está na iminência de morte ou de perda de função. [...] [Na] primeira etapa de estudos da célula-tronco, da sua biologia, tem-se visto que essa diferenciação ocorre, mas é um processo passível de discussão, uma vez que pode ocorrer fusão celular, existe uma perda de controle da expressão gênica da célula-tronco quando você a injeta no microambiente que pode fazer com que ela expresse proteínas que são comuns a outras populações celulares neuronais e que façam chegar à conclusão de que aquilo virou um neurônio, quando não virou.

O doutorando, discorrendo sobre o contexto do sistema nervoso, descreve a primeira hipótese de ação das células-tronco: a diferenciação em células desse sistema (os neurônios que transmitem os impulsos nervosos e as células da glia, que têm funções auxiliares). Uma segunda hipótese é que a ação terapêutica das células-tronco ocorre porque estas secretam substâncias que melhoram o ambiente das células que estão morrendo ou parando de funcionar. Na terceira hipótese, a ação das células-tronco se daria por meio da fusão com células do tecido lesionado. 
É difícil provar que a célula-tronco se diferenciou em outro tipo, porque a introdução dela em um microambiente distinto pode alterar a expressão de seus genes, de modo que ela mostre proteínas em sua superfície, proteínas estas que seriam marcadores característicos de células daquele local. Ele cita o exemplo de que a célula exibiria marcadores característicos de neurônios. Porém, esses marcadores não seriam prova suficiente de que a célula teria se tornado um neurônio. $\mathrm{O}$ mesmo doutorando prossegue:

A maneira mais segura de dizer que uma população celular virou outra coisa é fazendo testes funcionais: se aquela célula tem atividade elétrica, você analisa o perfil eletrofisiológico daquela célula para ver se tem uma impressão digital semelhante àquela população que você está estudando. [...] Revistas conceituadas têm uma crítica muito forte a você fazer um estudo em cima da expressão de algumas proteínas e dizer que aquela célula-tronco virou um neurônio, virou uma glia, virou um cardiomiócito. A hipótese de que as células estão secretando moléculas que dão suporte trófico para a vizinhança onde ela está tem ganhado força.

Ele propõe a aplicação de testes funcionais para avaliar se a célula possui atividade elétrica, como no caso dos neurônios. Destaco o uso do conceito de impressão digital das células: nesse ponto, ressalta-se a imagem antropomórfica do modelo celular. $\mathrm{O}$ depoente se remete à crítica formulada por autoridades científicas: mostrar proteínas não bastaria para afirmar que houve a transformação da célula-tronco em células do sistema nervoso (neurônio e glia) ou do músculo cardíaco (cardiomiócito). Por fim, ele defende a hipótese da secreção de fatores. Ele questiona, citando revistas conceituadas, o entendimento de que a expressão de proteínas indicaria a diferenciação da célula, o que seria um artefato e não um fato, e apresenta outras hipóteses. 
A primeira professora adjunta (52 anos) comenta as teorias sobre o funcionamento das células-tronco: a transdiferenciação, a secreção de fatores e a fusão.

Uma ideia é que funcionaria gerando células e restabelecendo uma população de células que foram perdidas. [...] Outra possibilidade é que essas células liberem também fatores [...] que venham a melhorar o microambiente, facilitando um processo de regeneração. [...] E tem uma ideia também de que as células se uniriam com outros tipos celulares, formando um híbrido celular, e agindo dessa maneira naquele tecido ali. Tem alguns pesquisadores que advogam essa terceira teoria. Não existe ninguém que tenha provado uma dessas hipóteses completamente.

Ela ressalta que nenhuma das teorias foi completamente provada, portanto não haveria ainda a estabilização desses enunciados. Comentando acerca da hipótese da transdiferenciação, a mesma professora questiona a diferença entre apresentar marcadores (morfologia) ou funcionar como célula-tronco.

Ninguém mostrou até hoje que uma célula que a gente injeta vá gerar um neurônio. O que já se mostrou [é] assim: essa célula passa a expressar um marcador de neurônio. Mas ninguém mostrou até agora se essa célula realmente é capaz de funcionar como um neurônio, fazendo sinapse, que essa sinapse seja funcional e que realmente essa sinapse venha a desencadear uma reação na outra célula. [...] Já existem estudos morfológicos mostrando que a célula passou a expressar proteínas que são típicas dos neurônios. Agora, se essa célula vai se comportar como neurônio [funcional] na sua totalidade, isso ainda está por ser descoberto. 
Como no relato de outros informantes, ela opóe morfologia e fisiologia: não basta expressar proteínas, é necessário o comportamento de um neurônio. Conforme mencionado nesta seção, o professor adjunto de 35 anos reconhece que a diferenciação de células embrionárias em progenitores neurais era "genérica", fundamentando-se apenas em marcadores. Três pesquisadores contestaram a interpretação. A evidência não bastaria para sustentar a hipótese da diferenciação. Constrói-se o fato científico com base nesse choque de ditas "evidências" físicas e diferentes interpretações. Fato ou artefato? Está-se ou não diante de um mesmo fato natural? A interpretação varia ou há vários modos de construir os fatos? O exemplo seguinte pode responder a essas perguntas.

A professora adjunta de 54 anos se refere à ação terapêutica das células-tronco, considerando que, ao invés de ser definida por algum tipo de mecanismo como a ação principal, os modelos experimentais podem iluminar os mecanismos: "Eu acho que depende muito primeiro do tipo de modelo que você está trabalhando. No momento, a gente fala em modelo, porque esses experimentos é que estão dando alguma luz ao mecanismo". A constatação do mecanismo depende do modelo experimental usado, isto é, o experimento faz o fato e sua teoria explicativa. Volta-se ao laboratório, como instância da construção dos fatos.

\section{Considerações finais}

O campo de pesquisa com células-tronco envolve expectativas de curas milagrosas e representaçôes de um futuro em que será possível "engenheirar" peças biológicas humanas. Novas formas de vida emergentes (Franklin, 2005), as células-tronco aqui foram objeto de análise com respeito à construção do fato científico: elas existem? Em contraste com a descrição pela divulgação científica e pela mídia, as células-tron- 
Revista de Antropologia, São Paulo, USP, 2013, v. 56 No 1.

co não consistem em um objeto unívoco no discurso dos cientistas que as pesquisam. O fato não foi adquirido ou o enunciado não se estabilizou, conforme os termos de Latour e Woolgar (1997). É possível isolar as tais células capazes de se transformar em qualquer coisa? As já "comprometidas" com um tipo de linhagem representariam células-tronco autênticas?

Nesse campo de investigação recente, a ação dessas células ainda não foi elucidada. Há teorias que podem ser encaradas como concorrentes ou simplesmente concomitantes. Essa controvérsia foi constatada entre os pesquisadores, que se dividiam em torno dos mecanismos de ação terapêutica das células. Não é da alçada da antropologia, uma ciência interpretativa, definir qual teoria seria verdadeira ou teria efeitos de verdade. Vários pesquisadores, no entanto, se sentiram motivados a comentar sobre a possibilidade de diferenciação, a teoria mais tradicional, que prega a plasticidade das células. Segundo essa teoria da diferenciação ou transdiferenciação, a célula aplicada se transforma por indução do meio na célula do tecido lesado, efetuando sua substituição e reparação. Usou-se esse tópico da biologia no artigo para se colocar o problema da construção do fato científico. A partir de quais critérios é possível validar uma hipótese? Há diferentes modos de construir e evidenciar a diferenciação, em particular a morfologia e os marcadores característicos das células. Existe um sério investimento na pesquisa básica de caracterização das células-tronco com base em seus marcadores a fim de identificá-las e, a partir de então, conhecer melhor suas funções no corpo e para terapias.

Com respeito à teoria da diferenciação ou transdiferenciação, alguns pesquisadores, hierarquizando entre forma e função, consideram que o aspecto funcional deve prevalecer sobre o morfológico. Não basta o fenótipo (aparência) da célula, pois a essência estaria na fisiologia. Será que as células funcionam como aquelas que deveriam substituir ou apenas as imitam? Hogle (2003) usou o termo "biomimetismo" para se re- 
ferir a esse aspecto: uma célula pode ser convertida para uso em parte corporal em local em que não seria normalmente encontrada, assumindo funções de outras, o que levanta novas possibilidades de design. Com respeito à construção do fato científico, viu-se como as técnicas criam novos fatos: as células-tronco hematopoiéticas são designadas segundo o teste reagente. Não há apenas hierarquias entre forma e função, mas a demonstração da dependência do laboratório para a construção dos diversos fatos.

Um dos objetivos do presente exercício de análise é demonstrar a construção social dos fatos naturais. Retoma-se aqui o debate clássico na antropologia, em torno da oposição entre Natureza e Cultura: a formação do vocábulo "bioengenharia", contexto futuro de aplicação das células, já sinaliza, a partir de seus radicais, para a importância desses elementos. Segundo Laqueur (1992), na cultura ocidental moderna, dentro do contexto do Iluminismo e da Revolução Francesa, houve uma mudança epistêmica na qual se passou a considerar a natureza como base da realidade, enquanto a dimensão social e cultural seria um epifenômeno. O corpo biológico, visto como estável e a-histórico, seria o fundamento para questōes da ordem social. A natureza se situa na ordem dos fatos. Neste artigo, no exame dos discursos que envolvem a construção da célula-tronco como fato científico, revela-se a articulação tensa entre dimensões ligadas à natureza e à cultura. Um dos exemplos é o uso da linguagem de parentesco acerca da reprodução e diferenciação das células: formação de linhagens e células designadas de mães, filhas, progenitoras. Outra dimensão referida é a oposição entre natureza e sobre natureza, quando as células classificadas pelos cientistas de pluripotentes ou multipotentes são redesignadas (Hogle, 2003) para outra função, tornando-se multiplicadores multitalentosos (Franklin, 2005). $\mathrm{Na}$ linguagem popular e da mídia, essas mesmas células entrarão no reino da sobrenatureza e serão chamadas de mágicas ou células do milagre. 
Revista de Antropologia, São Paulo, USP, 2013, v. 56 No 1.

Outra evidência do caráter socialmente construído dos fatos se encontra na retomada da história da constituição desse conhecimento, constatando-se a mudança de concepção de "fenômenos" ao longo do tempo, conforme constatado quando os pesquisadores mais antigos na academia assimilaram as células-tronco às células indiferenciadas existentes nos órgãos. Latour e Woolgar (1997) afirmam que os fatos recusam a ser sociologizados e querem voltar ao estado de exterioridade. Na presente investigação, constatou-se que alguns cientistas têm pouca familiaridade com a história das pesquisas com células-tronco e uma entrevistada chegou a afirmar a irrelevância de tal conhecimento, o que sugere a recusa da sociologização dos fatos: afinal, o conhecimento estabilizado, isto é, já inscrito nos livros, não exige mais atenção. Embora os mais antigos no campo apontem a continuidade com a proto-ideia de células indiferenciadas presentes em vários tecidos, é possível identificar o manto de novidade das células-tronco primeiramente na atribuição de potencialidade, e principalmente no emprego dessas células para muito além das terapias hematológicas estabelecidas, voltando-se para a intervenção clínica em outros tecidos e mesmo sua reconstrução na bioengenharia.

$\mathrm{Na}$ análise da argumentação acerca das teorias de funcionamento das células-tronco, verificou-se que evidências de laboratório foram usadas ou descartadas como insuficientes para construir o fato, relegadas ao estatuto de artefato. Tanto fato quanto artefato são construídos cientificamente no laboratório, estruturados culturalmente por intermédio da argumentação das controvérsias. Aliás, os cientistas duelam com suas armas: as interpretações de "fatos naturais" construídos em laboratório. Retomo aqui uma interrogação de Marilyn Strathern (1992) sobre as novas tecnologias reprodutivas: natureza assistida ainda é natureza? Ao contrário da concepção de que a natureza é a dimensão da realidade isenta do artifício técnico, no laboratório são construídas realidades naturais, como as células-tronco. Buscou-se apontar, nos relatos dos entre- 
vistados, que as células-tronco não constituem um objeto único: dúvidas se apresentam em torno de sua definição. O esforço para identificação e caracterização das células, em particular com o uso dos anticorpos monoclonais, criando classes de célula designadas de acordo com os reagentes, explicita o quanto a construção do fato científico depende do trabalho de laboratório.

Por fim, cabe relacionar a interrogação de Strathern (1992) sobre se natureza assistida é ainda natureza, com o conceito de biomimetismo proposto por Hogle (2003). Nas terapias com células-tronco, estas são deslocadas para outro ambiente e são redesignadas para funções próprias de outros tipos celulares. "Peças de reposição biológica" foi a expressão utilizada por um entrevistado para se referir a essa plasticidade. Mais uma vez se apresenta aqui o fluxo de significados de natureza e cultura, que conformam esse objeto. Ao se pretender redesignar as células-tronco para novas funçôes nas terapias, elas são representadas como mágicas, como células do milagre. Magia, mecânica, biologia. O estudo da construção do fato científico no exemplo das células-tronco, embora revele Natureza e Cultura como províncias ontológicas de instauração de sentidos, também indica a impossibilidade de divisão estanque entre o natural e o cultural.

\section{Notas}

Doutora em Antropologia pelo PPGAS, Museu Nacional (UFRJ), professora adjunta do Departamento de Ciências Sociais da Universidade Federal Rural do Rio de Janeiro e da Pós-Graduação em Ciências Sociais da UFRRJ. Pesquisa realizada na vigência de bolsa de fixação de pesquisador da FAPERJ no Laboratório de Estudos da Ciência (LEC) do Núcleo de Tecnologia Educacional para a Saúde (NUTES), UFRJ. 
2 Emprega-se o conceito de representação em sua acepção da sociologia clássica, conforme sintetiza Rodrigues acerca da análise de Durkheim: "Representaçôes coletivas, que são encaradas, num sentido estrito, como representaçôes mentais ou, melhor dito, representaçôes simbólicas, que, por sua vez, são imagens da realidade empírica" (Rodrigues, 1978: 21). Em Ciência em ação, Latour propõe o uso do conceito mais assemelhado ao da representação política, assim os cientistas são representantes de seus objetos de pesquisa como porta-vozes (Latour, 2000: 119), e desenvolve mais a crítica ao uso moderno de representação em Políticas da nature$z a$. Tal discussão da ontologia foge aos objetivos deste artigo.

3 Em 2007, houve a publicação de pesquisas mais recentes em que se reprogramaram células comuns a adquirir a pluripotencialidade das células-tronco embrionárias a partir de manipulação genética, o que seria um novo procedimento distinto da aplicação direta de células-tronco adultas. Cf.: Giovana Girardi, "Técnica gera célula-tronco sem embriāo: grupos no Japão e nos EUA reprogramaram células-tronco adultas da pele humana para agirem como se fossem embrionárias", Folha de S.Paulo, "Ciência", p. A18, 21 nov. 2007.

4 Para a obtenção dessas células, se aspira a medula óssea do paciente por punção. Esse aspirado é centrifugado e dele se extrai a "fração mononuclear", uma camada que concentra diversos tipos celulares, entre os quais as células-tronco.

5 Nesse ponto, é importante lembrar os conceitos de genótipo e fenótipo: o genótipo se refere à constituição genética e o fenótipo às características individuais determinadas pelo genótipo face às condições ambientais. As definições de fenótipo e de genótipo remetem à antiga oposição filosófica entre aparência e essência.

\section{Referências bibliográficas}

BOROJEVIC, Radovan

2004 "Terapias celulares: promessas e realidades". In Ciência Hoje, vol. 35, n. 206, pp. 37-39.

CARVALHO, Antonio Carlos Campos de

2001 "Células-tronco: a medicina do futuro". In Ciência Hoje, vol. 29, n. 172, pp. 26-31. 
ESCOBAR, Arturo

1994

"Welcome to Cyberia: Notes on the Anthropology of Cyberculture". In Current Anthropology, vol. 35, n. 3, pp. 211-231.

FLECK, Ludwik

1986 La génesis y el desarollo de un hecho científico. Madrid, Alianza Editorial.

FRANKLIN, Sarah

1995 "Science as Culture, Cultures of Science". In Annual Review of Anthropology, vol. 24, pp. 163-84.

2001 "Culturing Biology". In Health, vol. 5, n. 3, pp. 335-354.

2005 "Stem Cells R Us.: Emergent Life Forms and the Global". In ONG, A.; COLLIER, S. J. (eds.), Global Assemblages: Technology, Politics and Ethics as Anthropological Problems. Malden, Blackwell Publishing, pp. 59-78.

HARAWAY, Donna J.

1991

Simians, Cyborgs, and Women: The Reinvention of Nature. New York, Routledge.

HOGLE, Linda F.

2003

"Life/Time Warranty: Rechargeable Cells and Extendable Lives". In FRANKLIN, S.; LOCK, M. (eds.), Remaking Life and Death: Toward an Anthropology of Biosciences. School of American Research Press, Santa Fe; James Currey, Oxford, pp. 61-96.

LAQUEUR, Thomas

1992 Making Sex: Body and Gender from the Greeks to Freud. Cambridge/London, Harvard University Press.

LATOUR, Bruno

2000 Ciência em ação: como seguir cientistas e engenheiros sociedade afora. São Paulo, Unesp.

2004 Politicas da natureza: como fazer ciência na democracia. Bauru, EDUSC.

; WOOLGAR, Steve

1997 A vida de laboratório: a produção dos fatos científicos. Rio de Janeiro, Relume Dumará. 
LÖWY, Ilana

1994

"Fleck e a historiografia recente da pesquisa biomédica". In PORTOCARRERO, V. (org.), Filosofia, história e sociologia das ciências I: abordagens contemporâneas. Rio de Janeiro, Fiocruz, pp. 233-249.

LUNA, Naara 2006

"Terapias com células-tronco, a ética e a panaceia: uma análise antropológica das implicaçōes e representaçôes do uso de CT adultas e de embriōes". In $25^{a}$ Reuniāo Brasileira de Antropologia, Goiânia. 25a RBA CD ROM vol. 2, ABA Associação Brasileira de Antropologia.

MARTIN, Emily 1997

"Anthropology and The Cultural Study of Science: From Citadels to String Figures". In GUPTA, A.; FERGUSON, J., Anthropological locations: Boundaries and Grounds of a Field Science. Berkeley/Los Angeles, University of California Press, pp. 131-146.

PEREIRA, Lygia da Veiga

2002

Clonagem: fatos e mitos. São Paulo, Moderna.

SALEM, Tania

1997

"As novas tecnologias reprodutivas: o estatuto do embriāo e a noção de pessoa". In Mana, Rio de Janeiro, vol. 3, n. 1, pp. 75-94.

REHEN, Stevens; PAULSEN, Bruna

2007 Células-tronco: o que são? Para que servem? Rio de Janeiro, Vieira \& Lent.

RODRIGUES, José Albertino

1978 “A sociologia de Durkheim”. In RODRIGUES, J. A. (org.), Émile Durkheim: sociologia. São Paulo, Ática, pp. 7-37.

STRATHERN, Marilyn

1992

Reproducing the Future: Essays on Anthropology, Kinship and the New Reproductive Technologies. Manchester, Manchester University Press. 
SCHÄFER, Lothar; SCHNELLE, Thomas

"Los fundamentos de la vision sociológica de Ludwik Fleck de la teoria de 'la ciência". In FLECK, L., La génesis y el desarollo de un hecho cientifico. Madrid, Alianza Editorial, pp. 9-42.

\begin{abstract}
The article investigates speeches of scientists that take part in research projects with stem cells, including cell therapy, bioengineering and regenerative medicine. It is a work of ethnographic research with observation and semi-structured interviews that took place at a university. Scientists were interviewed and the study of their speeches clarifies the construction of stem cells as a scientific fact, which is related to the anthropological debate about nature and culture. The analysis of the speeches concerning the history of knowledge about stem cells and the hypotheses about their action reveals the dynamics of scientific truth construction. The aim is to explore science as culture by verifying the representations in speeches about stem cells. The laboratory is the central place for construction of scientific facts. The hierarchy of criteria for constitution of the cell's identity such as morphology and physiology are elements structuring the scientists' speeches.

KEYWORDS: Stem Cells, Construction of the Scientific Fact, Anthropology of Science.
\end{abstract}

Recebido em abril de 2011. Aceito em novembro de 2011. 